\title{
Fostering inclusion in art museums through mobile digital content
}

\author{
Željka Miklošević
}

Željka Miklošević, PhD, Assistant Professor

Faculty of Humanities and Social Science,

University of Zagreb

(Department of Information and Communication Sciences, Museology Unit)

Ivana Lučića 3, 10000 Zagreb, Croatia

e-mail: zmiklose@fffzg.hr

ORCID: 0000-0003-2742-3508

Muzeológia a kultúrne dedičstvo, 2021, 9:4:5-19

DOI: $10.46284 / \mathrm{mkd} .2021 .9 .4 .1$

\section{Fostering inclusion in art museums through mobile digital content}

This paper deals with digitally mediated museum experiences of novice visitors at the Kunsthistorisches Museum in Vienna and discusses them in the context of museum inclusion. Research participants included families with young children and members of minority communities in Vienna whose visit was facilitated by two app-based guided tours developed for children. The research goal was to explore the impact of the mobile guide's digital content and modes of communication on the visitors' interaction with the guide, with the museum space and objects, and with family members. The families' interactions were observed, recorded and analyzed. The results suggest that carefully considered and created content on mobile guides has the potential to provide novice family visitors with experiences that support their independence and active engagement, create opportunities for mutual facilitation, and support their different identities, all of which have been considered as conducive to inclusion.

Keywords: art museum, mobile guide, novice visitors, multimodality, inclusion

\section{Introduction}

Mobile interactive guides (handheld devices) have been widely used in museums to supplement individual physical exhibits and enhance visitors' experiences. Their unique functionalities include location-independent experiences, large quantities of varied information that can meet visitors' preferences, and various interactive features and modes of personal use that place visitors in control over the content. ${ }^{1}$

Instead of thinking of technology as a novelty and its attractive features as a simple panacea for museums' ailments, the use of new media in museums calls for thoughtful and strategic approaches to content development, as well as attention to different cultures of usage. This is especially true if technology being used to achieve cultural and social inclusion, in which case it is necessary to reflect on what the right approach might be and whether it will be relevant to the targeted communities. ${ }^{2}$ In his overview of the use of ICT in art museums, Peter Samis concludes that audiences care about "meaning: a memorable, emotionally compelling

\footnotetext{
${ }^{1}$ TALLON, Loïc. Introduction: Mobile, Digital, and Personal. In: TALLON, Loïc - WALKER, Kevin (eds.). Digital Technologies and the Museum Experience - Handheld Guides and Other Media. Lanham: AltaMira Press, 2008, pp. xvii-xviii. ${ }^{2}$ PARRY, Ross. Including Technology. Can New Media Really Help Museums to Meet the Inclusion Agenda. In: DODD, Jocelyn, SANDELL, Richard (eds.). Including Museums. Perspectives on Museums, Galleries and Social Inclusion. Leicester: Research Centre for Museums and Galleries, University of Leicester, 2001, p. 106
} 
experience"3 no matter what means are used to deliver it. Handheld interpretive devices, as only one type of ICT, have the potential to engage different types of visitors as long as their contents and affordances provide expected and desired experiences.

This research, grounded in the view that modes of museum communication are crucial for shaping visitors' experiences and attitudes to the institution, was conducted to explore digitally mediated experiences among families with young children during their first visit to the Kunsthistorisches Museum (KHM) in Vienna.

The rest of the paper is organized as follows: Section 2 provides an overview of the literature dealing with families as museum visitors and the use of digital handheld guides in art museums. Sections 3 and 4 present the research methodology and findings. Section 5 offers a discussion that covers the implications for further research and limitations of the study. The paper concludes with section 6 .

\section{Literature review}

As this study focuses on the use of digital mobile interactivity in an art museum, the review of the literature given in this section deals with three main relevant topics, namely, art museums in the context of access and barriers to engagement, families with young children as art museum visitors, and families' experiences related to the content and communication modes of digital mobile guides.

The environment of a typical art museum is mostly rooted in a formalist approach to exhibiting, which prioritizes the perception of form or an interpretational approach via an art history-based discourse. Hooper-Greenhill ${ }^{4}$ sees this as being related to the modernist paradigm according to which museums as institutions exercise the power of curators and art connoisseurs, that is, of someone who possesses knowledge not held by the less knowledgeable visitors. Decades-long research into art museums and galleries has provided information indicating that museums are perceived as exclusive in terms of class, ethnicity and education. ${ }^{5}$ Educated and experienced museum-goers who have developed familiarity with museums' codes are more likely to have meaningful experiences and develop a feeling of belonging. ${ }^{6}$ Conversely, visitors with little or no art museum experience may not show any appreciation for the art they encounter in such spaces. As Peter Samis reports, interpretive resources in art museums might be crucial for uninitiated visitors' engagement in or withdrawal from the experience. ${ }^{7}$ Although art museums have been working on facilitating experiences with art works for diverse audiences by providing different kinds of interpretative material, this

\footnotetext{
${ }^{3}$ SAMIS, Peter. Revisiting the utopian promise of interpretive media. An autoethnographic analysis drawn from art museums, 1991 - 2017. In: DROTNER, Kirsten - DZIEKAN, Vince - PARRY, Ross - SCHRØDER, Kim Christian (eds.). The Routledge Handbook of Museum, Media and Communication. London: New York: Routledge, 2009, p. 63 ${ }^{4}$ HOOPER GREENHILL, Elaine. Museums and the Shaping of Knowledge. London: New York: Routledge, 1992 , p. 7. ${ }^{5}$ ANG, Ien. Change and Continuity, Art Museums and the Reproduction of Art Museumness. In: WITCOMB, Andrea - MESSAGE, Kylie (eds.). The International Handbooks of Museum Studies: Museum Theory, vol 2. Disciplines and Politics. Hoboken: John Wiley \& Sons, Ltd, 2015, p. 214.

${ }^{6}$ O’NEILL, Mark. The Good Enough Visitor. In SANDELL, Richard (ed.). Museums, Society, Inequality. London: New York: Routledge, 2003, p. 35.

7 SAMIS, Peter. Gaining Traction in the Vaseline: Visitor Response to a Multi-Track Interpretation Design for Matthew Barney: DRAWING RESTRAINT. In: TRANT J. - BEARMAN D. (eds.). Museums and the Web 2007: Proceedings. Toronto: Archives \& Museum Informatics, 2007, accessed October 1, 2020. http://www.archimuse.com/ mw2007/papers/samis/samis.html
} 
has not become widespread practice. Adams and $\mathrm{Koke}^{8}$ found reasons for the still-pervasive resistance to change include the predominant curatorial expertise in exhibition development, institutional structural issues, collection organization, and the absence of community voices. Regarding children and youth as specific audience groups, making art museums more inclusive for such groups has been achieved mainly through short-term projects and specially designed programmes. ${ }^{9}$

Families go to museums because they hope the visit will have educational benefits for the children, provide an opportunity to spend time together, and offer an enjoyable experience. ${ }^{10}$ In addition to comfortable spaces where children can freely explore, one of the most preferred features of museums for families is interactivity. One way that art museums provide interactive experiences on a more permanent basis is through specially designed interactive galleries, which, in a way, prepare families for visiting the permanent exhibitions. These galleries seem to be successful in stimulating interest in and learning about objects; however, research has found that repeated visits are needed in order to increase visitor's familiarity with the museum before they feel willing to visit the permanent exhibition. ${ }^{11}$ Despite their success, these spaces may be construed as contributing to the "othering" of children ${ }^{12}$ by removing them from permanent exhibitions as the spaces that have traditionally been reserved for adult visitors. ${ }^{13}$

Researching adult-child interaction at an interactive art exhibition which was equipped with fixed multimedia interpretation, Stéphane Debenedetti and colleagues ${ }^{14}$ found that the children enjoyed using interactives and that they spent more time in front of the art works in the close proximity of these devices. Such an approach to exhibition-making can fulfil the goal of every art museum, which is to have visitors focus on the original artworks. However, this study showed that the communication between adults and children was reduced to a mere transference of information provided by the panels, which the authors explain by the failure of the interpretive resources to enable adults to engage children or encourage them to engage themselves in the experience, both cognitively and emotionally.

\footnotetext{
${ }^{8}$ ADAMS, Marianna - KOKE, Judy. "Stuck" Is Where You Need to Pay Attention. Some Barriers to Creating Truly Inclusive Art Museums. In: BOYD, Joni Acuff - EVANS, Laura (eds.). Multiculturalism in Art Museum Today. Lenham, Maryland: Rowman and Littlefield, 2014, pp. 3-18

${ }^{9}$ JOHANSON, Katya - GLOW, Hilary. 'It's not enough for the work of art to be great': Children and Young People as Museum Visitors. In: Participations - Journal of Audience and Reception Studies, 9(1), 2012, p. 28.; WEIER, Katrina. Empowering Young Children in Art Museums: Letting Them Take the Lead. In: Contemporary Issues in Early Childhood, 5(1), 2004, pp. 107-108.

${ }^{10}$ MCMANUS, Paulette M. (1994). Families in Museums. In: MILES, Roger - ZAVALA, Lauro (eds.). Towards the Museum of the Future: New European Perspectives. London: York: Routledge, 82-83;

${ }^{11}$ ADAMS, Marianna - LUKE, Jessica - ANCELET, Jeanine. What Do We Do and Not Know about Family Learning in Art Museum Interactivity Spaces - Family Learning in Interactive Galleries, 2010, accessed June 6, 2019, http://www.familiesinartmuseums.org/images/pdf/CompleteFLINGLitReview.pdf.

${ }^{12} \mathrm{BIRCH}$, Jo. Museum spaces and experiences for children - ambiguity and uncertainty in defining the space, the child and the experience. In: Children's Geographies, 16(5), 2018, p. 517.

${ }^{13}$ GRØN, Karen. Empower the Audience! Audience through Deliberate and Strategic Use of Experience and Learning Theories. In: FRITSCH, Juliette (ed.). Museum and Gallery Interpretation and Material Culture. London: New York: Routledge, 2011, p. 208.

${ }^{14}$ DEBENEDETTI, Stéphane - CARO, Florence - KREBS, Anne. "I'd Rather Play Than Look at Statues": The Experiences of Children with Art Works and Interactive Devices at an Art Exhibition, In: International Journal of Arts Management, 11(3), 2000, p. 56
} 
Providing information on interactive mobile guides in art museums has been proven beneficial for different aspects of visits. ${ }^{15}$ However, empirical research shows that the relationship between what is interpreted and how can be crucial for a balanced experience one that does not privilege digital content over original exhibits or one's visit companions.

Mobile guides with augmented reality features enhance the visual information that visitors receive from the original objects and this is what contributes to longer and more focused engagement with displayed art work, especially in comparison with generic digital guides. ${ }^{16}$

Storytelling-especially its humorous aspects, links to everyday contemporary life, an informal tone, and unconventional characters are appealing to most visitors, but especially to children. ${ }^{17}$ In their research, Rubino and colleagues ${ }^{18}$ explored the impact of different communication approaches on learning for adult and young visitors. They demonstrated that a combination of the physical environment, virtual characters, microgames, and cultural contents have a positive impact on visitors' memory skills. Another important realization stemming from their research is that informal style stimulates children but discourages adults from using the game as they perceive it as childish. The implication of this is that museum should develop different content for adults and children, which complements Helal, Maxson and Ancelet's findings that parents would like mobile guides whose content is more adapted to children. ${ }^{19}$

Recent studies on the use of mobile digital interactives by families show that visitors adopt different patterns of use and in-group behaviour, ${ }^{20}$ which might depend on their visit motivation and family dynamics.

These and similar investigations provide valuable insights into how different communication modes and the content of digital interpretation resources can impact museum experiences, primarily in terms of visitor satisfaction, levels of engagement and learning. However, little attention has been paid to the impact that these and other aspects of ICT use have on the perception of the museum as an institution, especially among non-visitors. In order to fill the gap in the literature, this study expands the research field of mediation in art museums to novice families with young children. It focuses on the ways in which mobile digital content shapes their art museum experiences and, in turn, explores the power of digital devices in terms of its wider sociocultural importance in the context of museums.

\footnotetext{
${ }^{15}$ GIUSTI, Ellen. Improving Visitor Access. In TALLON, Loïc - WALKER, Kevin (eds.). Digital Technologies and the Museum Experience - Handheld Guides and Other Media. Lanham: AltaMira Press, pp. 97-108; SAMIS, Peter. Revisiting the utopian promise... pp. 58 - 59 .

${ }^{16}$ CHANG, Kuo-En - CHANG, Chia-Tzu - HOU, Huei-Tse - SUNG, Yao-Ting - CHAO, Huei-Lin - LEE, Cheng-Ming. Development and behavioral pattern analysis of a mobile guide system with augmented reality for painting appreciation instruction in an art museum. In: Computers \& Education, 71, 2014, p. 192.

${ }^{17}$ ROUSSOU, Maria - KATIFORI, Akrivi. Flow, Staging, Wayfinding, Personalization. Evaluating User Experience with Mobile Museum Narratives. In: Multimodal Technologies and Interaction, 2, 2018, p. 16.

${ }^{18}$ RUBINO, I. - BARBERIS, C. - XHEMBULLA, J. - MALNATI, G. Integrating a location-based mobile game in the museum visit: Evaluating Visitors' Behaviour and Learning. In: Journal on Computing and Cultural Heritage, 8(3), 2015, pp. 11-14.

${ }^{19}$ HELAL, Dina - MAXSON, Heather - ANCELET, Jeanine. Lessons Learned: Evaluating the Whitney's Multimedia Guide. In: PROCTOR, Nancy - TELLIS, Chris (eds.). Museums and the Web 2013. Silver Spring, MD: Museums and the Web, 2013, accessed May 29, 2019. https://mw2013.museumsandtheweb.com/paper/lessons-learned-evaluating-the-whitneys-multimedia-guide/.

${ }^{20}$ RENNICK-EGGLESTONE, Stefan - BRUNDELL, Patrick - KOLEVA, Boriana - ROUSSOU, Maria CHAFFARDON, Christophe - BENFORD, Steve. Families and mobile devices in museums: designing for integrated experiences. In: Journal on Computing and Cultural Heritage, 9(2), 2016, pp. 6-8.
} 


\section{Research methodology}

\section{1. Theoretical framework}

This research was based on the socio-semiotic theory of multimodal communication and multimodal ethnography. As has been mentioned earlier in the text, art museum exhibitions are often seen as spaces for the representation of specialist knowledge, and their sociocultural power operates through discourses intended for a particular group of visitors. Focusing on the intentionality of communicative acts and their relation to social power, ${ }^{21}$ social semiotics is employed to theoretically frame the investigation into the museum's digital guide as a mode of communication motivated by the wish to establish meaningful relationships with underrepresented visitors. The focus of the research, therefore, treats the discourse, style, genres and modality of the mobile guide as elements of social semiotics that can reveal power relations within communicative acts in particular cultural sites and social occasions ${ }^{22}-$ in this case in the Kunsthistorisches Museum. A multimodal approach to communication contributes to the understanding of the role and value of different modes such as image, sound and action in visitors' experiences and responses. ${ }^{23} \mathrm{~A}$ mutual complementarity between social semiotics and multimodal ethnography lies in their shared focus on meaning-making through cultural and social practices that unfold in time and in a particular cultural setting. ${ }^{24}$ This study draws on Pink's multimodal ethnography, which pays attention to sensory aspects of research. ${ }^{25}$ In order to reveal the communicative acts as they occur, the researcher records participants' behaviour, including their embodied sentiments produced during interaction with the environment, which in this study is related to interactions with the mobile guide, space, exhibits and other participants. This makes fieldwork an activity that directs the focus of the researcher to both the cognitive and the emotional dimensions of the visit, or to what matters to the communities that participate in the study. ${ }^{26}$ Drawing on these approaches, this study aims to provide an answer to the research questions: how does the use of the digital museum guide impact the experience of novice museum visitors, and what impact might that experience have, if any, on the perception of the museum as an institution in terms of its inclusivity?

\section{2. Setting and method}

The mobile guide in focus is the Kunsthistorisches Museum Stories (hereinafter referred to as KHM Stories), an app that can be downloaded to personal smart phones for free and used in and outside the museum. It is one of very few apps developed for an art museum that offers specifically developed content for children and families and is, in addition, translated into the languages of various local communities.

At the time of research there were two stories developed for children, namely, How to Look for Monsters and Superpower. The stories are shaped as theme-based guided tours that comprise

\footnotetext{
${ }^{21}$ KRESS, Gunther. Multimodality - a social semiotic approach to contemporary communication. London: New York: Routledge, 2010, p. 22.

${ }^{22}$ VAN LEEUWEN, Theo. Introducing Social Semiotics. London: Routledge, 2005, pp. 93-177.

${ }^{23}$ JEWITT, Carey. Digital technologies in museums: New routes to engagement and participation. In: Design for Learning, 5(1-2), 2012, pp. 74-93.

${ }^{24}$ DICKS, Bella - BAMBO, Soyinka - COFFEY, Amanda. Multimodal Ethnography. In: Qualitative Research, 6(1), 2006, pp. 77-96.

${ }^{25}$ PINK, Sarah. Multimodality, multisensoriality and ethnographic knowing: Social semiotics and the phenomenology of perception. In: Qualitative Research, 11(3), 2011, p. 271.

${ }^{26}$ LUTZ, Catherine. What matters. In: Cultural Anthropology, 32(2), 2017, p. 189.
} 
eight and nine stations respectively, which means eight and nine museum objects exhibited at the permanent exhibition and interpreted through different modes of communication. The tours for children are envisaged to provide experiences adapted to their age. Both tours are translated into the languages of the largest minority communities living in Vienna, namely, Turkish, Serbian, Croatian and Bosnian.

The research was conducted in February and March 2018 with families of Bosnian, Croatian and Serbian origin who had lived in Vienna for at least one year before the start of the research. For the purpose of this study, a family has been defined as consisting of at least one adult and one child, ${ }^{27}$ and novice visitors refers to people who do not visit art museums and are new to interpreting and experiencing art in these institutions. The research participants included ten families with at least one seven- or eight-year-old child per family (Table 1).

Tab. 1: Families that participated in the research

\begin{tabular}{|c|c|c|c|}
\hline Family groups & Family members & \multicolumn{2}{|l|}{ Codes } \\
\hline F1 & Mother + son $(8)+$ daughter $(17)$ & \multicolumn{2}{|c|}{ F1M, F1S, F1D } \\
\hline F2 & Mother + daughter $(7)$ & \multicolumn{2}{|c|}{ F2M, F2D } \\
\hline F3 & Father + daughter $(8)$ & \multicolumn{2}{|l|}{ F3F, F3D } \\
\hline $\mathrm{F} 4$ & Mother + daughter $(8)$ & \multicolumn{2}{|l|}{ F4M, F4D } \\
\hline F5 & Father + son $(7)+$ daughter $(10)$ & \multicolumn{2}{|c|}{ F5F, F5S, F5D } \\
\hline F6 & Sister $(+18)+$ brother $(8)$ & \multicolumn{2}{|l|}{ F6S, F6B } \\
\hline F7 & Mother + daughter $(7)+$ daughter's friend (7) & \multicolumn{2}{|c|}{ F7M, F7D, F7F } \\
\hline F8 & Mother $+\operatorname{son}(7)$ & \multirow{2}{*}{$\begin{array}{l}\text { F8M, F8S } \\
\text { F9M, F9S }\end{array}$} & \multirow[t]{2}{*}{ (visited together) } \\
\hline F9 & Mother $+\operatorname{son}(8)$ & & \\
\hline F10 & Mother + daughter $(7)$ & \multicolumn{2}{|l|}{ F10M, F10 } \\
\hline
\end{tabular}

Data on behaviours, reactions and interactions with museum objects, the space, the digital content and amongst themselves were gathered through participant observation and interviews with the families. The tours began at the museum lobby from where the participants (including the researcher) were guided by the digital device to each station. Before and after the visit, the families were interviewed with the aim of finding out information about their everyday use of digital technology (primarily the children's behaviour with and around digital content, such as frequency and type of content with which they interact most often), their previous experience with the museum, and reflections on the gained experiences and advantages or disadvantages of the guide in the context of their visit. Interview questions were mainly directed at the parents, though the children were present and could participate actively in the conversation. Each family group did one tour, and the duration of the visits ranged from 60 to 100 minutes.

The gathered data included extensive field notes and verbatim transcripts of audio recordings of the participants' conversations, reactions in the physical space, and views about the museum before, during and after the visit. The qualitative textual data were thematically analysed. Methodological limitations related to the lack of visual recordings in the analysis of visitors' behaviour, which could have contributed to more nuanced results.

${ }^{27}$ FALK, John H. Analysis of the behaviour of family visitors in natural history museums. In: Curator, 34(1), 1991, p. 45. 
4. Findings: Three ways in which the museum can present an environment that fosters inclusion

The main framework for the interpretation of the obtained data was determined by the aim of the research. The findings have been conceptualized as three characteristics of the museum environment shaped by the use of the digital guide and conducive to inclusivity for this particular group of visitors.

\subsection{An environment that supports independent engagement}

During the visit to the KHM, the children's focus and interest were maintained by different types of activities provided by the guide. Different characters tell stories in an informal way, in "everyday language", posing questions and directing attention to details on exhibits. Recorded speech, animation of paintings and possibilities to take a selfie as Hercules holding a surfing board or as an Amazon warrior playing tennis created moments of fun and enjoyment for all family members with a high degree of mutual interaction.

Narrative texts of the guide introduced the families with the displayed objects by providing information related to different contexts such as mythology, popular culture, the animal world, historic events and so on. Solving quizzes about individual artworks generated a genuine excitement and evoked a wide range of emotions in the children. Choosing the right answer often resulted in exclamations of joy and gestures such as a clenched fist (one that communicates success or victory), whereas failing to get it right first try brought about a short-lasting disappointment, after which they went on with the guessing game until the sign "correct" appeared on the screen. Drag-and-drop and colouring, as a hands-on activity in which children can make their own unique creation, was engaging for both children and parents and turned them into active participants in the co-creation of content, which they could then share through social media.

The multimodal content and dynamic exchange of genres kept children engrossed in listening or reading the stories, watching videos, observing objects in search of details, answering questions, etc. The children were so absorbed in the activities that they were surprised when the tour finished. Their disappointed and surprised exclamations "Is it over so soon?" (F2D), "It's ended so quickly!" (F8S), show that they did not "feel" the time passing even though the average time they spent using the guide was 45 minutes.

The families were guided through the museum either by reading the characters' instructions on where to go or by comparing the digital image of the interior and their current location in the physical space. This feature of the guide was interesting to children who compared it to a navigation system. With the guide in their hands, they moved through the museum independently and confidently, sometimes even too fast for their parents, who let them lead the way. Letting children take the lead and direct their own experience can contribute to their sense of participation and involvement, by showing them they "have a valuable contribution to make". ${ }^{28}$ For both children and parents, the use of the guide was such an interesting and exciting experience that they expressed a wish to visit the museum again.

4.2. An environment that creates opportunities for knowledge-sharing and mutual facilitation

The adult-child relationship during the museum visit is very important for the family

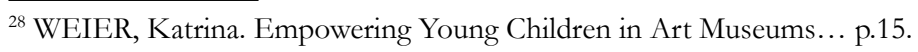


experience, which, as has already been mentioned, is very often directed at learning, with parents mostly acting as facilitators wherever possible. ${ }^{29}$

The digitally mediated experience at the KHM generated negotiations between family members in terms of who was in charge of the visit and who acted as facilitator. Children showed great orientation skills in using the digital content, and also provided scaffolding for their parents, particularly for those who did not use the guide consistently and synchronously with the child. Since they did not access the same information, the children were more "in-theknow" when it came to information about the objects, the meanings of some of their elements, and so on. Realizing their children felt comfortable in their position of leaders and knowledge distributors, the parents let them have that experience.

Knowledge-sharing was present where the interaction between the child and the parent intensely revolved around information that they both obtained from the guide, which was evident in the exchange of questions and exclamations such as, "did you know that?!" and "did you hear that?!".

Some parents were consistent in trying to slow down their children's pace, direct their attention to objects, and instruct them to be more careful and focused when looking at the exhibited art works, or when reading or listening to the stories about them (probably due to the common belief that museums, especially art museums, are about looking at objects).

Parents positively reacted to children's inquisitiveness and interests and continued conversations about the displayed objects by providing additional explanations and prompting extended observation.

F2D: Mum, look! They are up there!

F2M: Yes, dead people are painted in a different colour, some sort of grey. Look how the women are pale!

The guide assisted both children and parents in meaning-making and appreciation of objects through interactive explorations of concepts. Parents provided explanations for certain words when and where needed. "Rome", "bronze" and "linen" (the material), were some of the terms they explained by making associations with something from everyday life, such as clothes, jewellery, films they had seen or stories they had read at home.

F4D: Amazons?! What is that?

F4M Listen, they are brave warriors (both listening)

F4D: Look! (pointing to the sarcophagus with the relief of Amazons whose parts are missing)

F4M Yes, it's fallen off (both listening) ... Riiight! For the city of Troy (referring to the battle shown on the sarcophagus) Do you remember Troy - I told you about that huge horse that was brought inside with bidden warriors in it and then they won...

F4D: I think I know...

Conversations and knowledge-sharing seemed not to have been dependent on anything particularly related to the digital content and functionalities of the device but rather on the dynamics of visits, individual interests and mutual interaction patterns among family members.

\subsection{An environment that supports different identities}

One of the biggest advantages of digital technology is that it can deliver information in ways that suit different learning styles. Holding their own phone in one hand, and operating it with the other, both children and parents could choose whether to read texts on the device or

${ }^{29}$ FALK, John. Identity and the Museum Visitor Experience. London: New York: Routledge, 2009, p. 87. 
to listen to audio recordings. The images which accompanied the written texts and/or audio recordings functioned as successful meaning organizers, attracting attention and encouraging the families, particularly the children, to further explore the content. They could choose to listen or read additional stories on the page "More information" or engage in other activities that occupied the children's attention. Reading texts could not be avoided in the majority of quizzes but we found it was mostly skipped where listening was offered as alternative. This sort of digital behaviour stems from the children's daily use of digital devices, either mobile phones or tablets, on which they play video games or watch YouTube clips. The influence of everyday digital habits manifested in the first 10 minutes of the visit when, after the first introduction with the guide, they quickly mastered all its functionalities. This also included children whose parents reported not allowing them to spend much time on smartphones.

Awareness of the children's enjoyment made the parents feel relaxed and satisfied about their decision to invest personal time and bring the children to the museum. In the interviews before the tour, parents reported having made, on several occasions, family visits to the Natural History Museum and the Technical Museum in Vienna. However, they had never had a wish to visit the Kunsthistorisches Museum before, because they had perceived it as not offering anything interesting to children. However, once they learnt about the guide and its entertaining and educational features, they decided to come. They initiated a museum-based activity in order to create opportunities for their children to gain experiences which might entertain and educate them.

After the visit, the changed perception of the museum was based on parents' own experience and children's wish to come back again (tomorrow!) or to do the whole thing again but with another story. However, the parents did more than see their children as suitable users of this art museum. They marked it as a place on their own leisure map when they realized they could come again to try the stories for adults.

F8S: Mum, before I turn 19, I can come here alone, for free?

F8M: Yes, but you cannot come alone.

F8S: Yes, but Mum, you can come with me to the entrance and wait for me there.

F8M: (laughing) Mum (referring to herself) can also come again and learn something new. ... Aunty (referring to F9M) and I will come and do one tour slowly and thoroughly without you kids running around...

The feeling of belonging or being accepted was reinforced by the use of ex-Yugoslav languages (Bosnian, Croatian, Serbian). The fact that the knowledge communicated through this guide was in the visitors' language(s) was seen not only as welcoming but also necessary, due to the sizeable community of ex-Yugoslav citizens in Vienna. The recognition here is both cultural and sociopolitical. Another type of impact of the language on the feeling of recognition and inclusion was that felt by parents whose command of German was below the level used in the museum. For them, the guide's content was more accessible in their language and they could share the experience with their children, even if the children chose to interact with the app's content in the German language.

On the other hand, for children who had just started school, German could also be problematic, so the mother tongue can be regarded as a tool that both enables children's comprehension of the digital content and helps parents to assume the role of facilitators and provide explanation of certain words or assistance in reading textual information. The sociocultural closeness that the museum established through language was important for parents whose knowledge of 
German was limited. For them, that feature of the guide was a welcome opportunity to access the cultural richness of the museum with greater ease.

\section{Discussion: Towards inclusion through digital content}

Traditionally, art museums have been more focused on providing access to original artworks than different meanings of or about them, and there is still reluctance among numerous institutions to transform themselves into inclusive environments for broader audiences. The findings of this research indicate the potential that well-designed content and modes of communication via a mobile digital guide can have for overcoming some of the barriers to cultural participation for uninitiated family visitors in traditional art museums.

Firstly, the digital guide can be seen as a tool that can appease the polarised views of what the space of an art exhibition should be like and for whom it should be designed - in particular, the people who need more and diverse information about art or those who do not. ${ }^{30}$ Digital mediation via a mobile guide can make art museums equally intellectually accessible and enjoyable to a wide range of visitors, and provide each individual, at the same time and in the same space, with different experiences of art, whether aesthetic, contextual or interactive. Without causing any disruption for those who enjoy the pristine spaces of art museums and galleries, digital resources can help novice families feel more included in the cultural practice. This particularly concerns children accompanied by parents, who are often isolated in specially designated spaces. Using digital content adapted to their age, children can participate equally with adults in the principal museum space, i.e., the exhibition galleries, and can be in contact with original artworks, which decreases the ghettoizing effect. ${ }^{31}$

Secondly, by encouraging and enriching personal and social meaning-making, digital content can turn family members into self-reliant and independent visitors in seemingly uninviting spaces filled with art and information about art history. This is true for both children and adults. The features that enable this relate primarily to the informal style of communication, the narrative genre, and the approach to interpretation of museum objects that enable visitors to forge a connection between the museum and their everyday lives. Connecting object-related topics with children's pre-existing knowledge and interests fosters meaningful experiences and raises the educational and cultural value of the museum environment. ${ }^{32}$ When visiting museums, children prefer family over school trips because they can exert more control over the visit within the family group. ${ }^{33}$ With control and choice comes a higher level of motivation leading to a bigger interest and engagement without conscious awareness of the activities or the passing of time, which is when people "experience the highest levels of well-being". ${ }^{34}$ Additionally, deep enjoyment and involvement can lead to attribution of significance to an activity. ${ }^{35}$

\footnotetext{
${ }^{30}$ LATIMER, Sue. Art for Whose Sake? In: FRITSCH, Juliette (ed.). Museum Gallery Interpretation and Material Culture. London: New York: Routledge, 2011, pp. 67-79.

${ }^{31} \mathrm{BIRCH}$, Jo. Museum spaces and experiences for children, p. 517

${ }^{32}$ PISCITELLI, Barbara - ANDERSON, David. Young children's Perspectives of Museum Settings and Experiences. In: Museum Management and Curatorship, 19(3), 2001, p. 279.

${ }^{33}$ JENSEN, Nina. Children's Perceptions of Their Museum Experiences: A Contextual Perspective. In: Children's

Environments, 11(4), 1994, p. 311

${ }^{34}$ CSIKSZENTMIHALYI, Mihaly. Flow and the Foundations of Positive Psychology. Dordrecht: Springer, 2014, p. 72

${ }^{35}$ PARIS, Scott. Situated Motivation and Informal Learning. In: Journal of Museum Education, 22(2-3), 1997, p. 23.
} 
Thirdly, children's learning experiences, including enjoyment as an important aspect of learning, are highly regarded by parents, who, by using accessible digital content, can also discover interesting things for themselves and be engaged in activities and, in turn, empowered by the museum. This holds important implications for art museums, especially in relation to the research that shows that the role of museums as cultural places that build social distinction has been changing due to the changing role of the families who privilege construction of their children's identities and their personal development over the transmittance of social status and social values onto their children. ${ }^{36}$ Parents can be effective facilitators for their children's learning when exhibitions are designed with collaborative learning in mind and when adults feel comfortable with the content and experiences provided in the museum ${ }^{37}$ In this way, they can fulfil their role as parents who recognize opportunities for learning and the cultural development of their children, as well as for themselves.

Lastly, barriers to art experiences can be intellectual, but also linguistic, especially in this time of frequent migrations, in Europe in particular. Recognizing the need to speak the language of minority communities is another step institutions can make towards removing barriers to minorities' participation in arts and culture and the recognition of their cultural identity. Digital resources can help the art museum to make a dent in breaking its image of exclusivity and instead create an environment where families with no or little knowledge of art can still actively participate in the social and cultural practice of museum-going, whether for the sake of children or not. According to Mark O’Neill, a socially inclusive art museum treats all visitors with equal respect by "providing access appropriate to their background, level of education, ability and life experience". ${ }^{38}$ Museum experiences that promote self-sufficiency, engagement and relevance can build individuals' confidence and self-esteem in their future social and cultural life. In addition to access and participation, representation is recognized as integral to the cultural dimension and inclusion. ${ }^{39}$

However, when it comes to participation as an opportunity to participate in cultural production, and representation as the "extent to which an individual's cultural heritage is represented within the mainstream cultural arena", ${ }^{40}$ this particular museum could take more substantial steps towards inclusivity. Although language is a powerful cultural marker and an important aspect of representation and although the research results suggest it is a factor that has potential to form stronger ties between the museum and the minority communities, it is still just a mediating tool of the content that was not developed with the minority cultures in mind. All the information presented digitally is still related to the universal value of the historical art pieces in the museum's collection. One way in which this app could be developed to embrace all the elements of the cultural inclusion dimension might be to contain culturespecific narratives, which would require consultation with community members and a different approach to the discourse of the app stories. The content might include references, no matter how tangential, to the art and culture of minority communities and not be a mere translation

\footnotetext{
${ }^{36}$ JONCHERY, Anne - BIRAUD, Sophie. Musées en famille, familles au Musée. De l'expérience de visite des familles à des politiques muséales spécifiques. In: Informations Sociales, 1(181), 2014, pp. 89-90.

${ }^{37}$ FALK, John H. - DIERKING, Lynn D. Learning from Museums. Visitor Experiences and the Making of Meaning. Walnut Creek, CA: AltaMira Press. 2000, p. 95

${ }^{38}$ O’NEILL, Mark. The Good Enough Visitor... p. 24

${ }^{39}$ SANDELL, Richard. Museums as Agents of Social Inclusion. In: Museum Management and Curatorship, 17(4), 1998, p. 410.

${ }^{40}$ SANDELL, Richard. Museums as Agents... p. 410.
} 
into another language. Extending the stories into the realms that are linked to the historical, geographical and artistic background of these communities might have much deeper meaning and representational value and might move beyond the effect of increasing attendance of underrepresented visitor groups. Another important aspect of inclusivity is the impact on the people and their lives within particular communities; ${ }^{41}$ however, it would be necessary to conduct further research to uncover this. The mobile guide can be seen as good motivation tool but longitudinal research is needed to determine the possible long-term effects of a mediated museum experience. What also needs to be noted is that due to the exploratory nature of this study the results cannot be generalized; further research might therefore include a quantitative approach and a more in-depth look into the museum-going habits and digital participation of these communities.

\section{Conclusion}

As digital mobile guides have been assuming an increasingly important role in museums as information-rich resources that provide personalized experience to visitors, this research aimed to explore views and attitudes of novice family visitors to the Kunsthistorisches Museum based on a museum experience supported by the use of a digital guide. Research participants included families with young children from ex-Yugoslav communities living in Vienna, who represent large minority groups in the city and who have been largely underrepresented among the museum's audiences. Data about participants' behaviour during their visit and details of their experience were gathered through observation and interviews. The obtained data were interpreted and conceptualized from the position of the museum as a place or environment that can support specific sociocultural and personal profiles of the audience. The findings show that the use of the digital interpretive tool helped the research participants to engage with the physical space and exhibits independently, both as individuals and as a family; created opportunities for them to share knowledge and facilitate each other's learning process; and made them feel recognized in terms of their learning and cultural identities.

Digital mobile guides can be powerful interpretation tools for shaping experiences of novice museum visitors from minority communities and can contribute to forging new museum audience relationships, as well as establishing relevance by removing barriers to cultural participation, especially in traditional spaces such as art museums. Speaking in terms of museum communication, carefully designed modes and modalities of digital communication may lead to a change in social relations between the "elitist" art museums and visitors with little knowledge about art.

This paper has been fully supported by the Croatian Science Foundation under the project Art and the State from the Enlightenment to the Present, IP-2018-01-9364. The research was conducted as an STMS within the COST ACTION IS1410 Digital literacy skills and practices in the early years (DigiLitEY).

\footnotetext{
${ }^{41}$ NEWMAN, Andrew - MCLEAN, Fiona. Architectures of Inclusion: Museums, Galleries and Social Inclusion. In: SANDELL, Richard (ed.). Museums, Society, Inequality. London: New York: Routledge, 2003, 56-68.
} 


\section{References}

ADAMS, Marianna - KOKE, Judy (2014). "Stuck" Is Where You Need to Pay Attention. Some Barriers to Creating Truly Inclusive Art Museums. In: BOYD, Joni Acuff - EVANS, Laura (eds.). Multiculturalism in Art Museum Today. Lenham, Maryland: Rowman and Littlefield, 3-18. ISBN 9780759124103

ADAMS, Marianna - LUKE, Jessica - ANCELET, Jeanine (2010). What Do We Do and Not Know about Family Learning in Art Museum Interactivity Spaces. Family Learning in Interactive Galleries, accessed June 6, 2019. http://www.familiesinartmuseums.org/images/ pdf/CompleteFLINGLitReview.pdf.

ADAMS, Marianna - LUKE, Jessica - MOUSSOURI, Theano (2004). Interactivity: Moving beyond Terminology. In: Curator 47(2): 154-170. ISSN 0011-3069

ANG, Ien (2015). Change and Continuity, Art Museums and the Reproduction of Art Museumness. U: Witcomb, Andrea - Message, Kylie (eds.). The International Handbooks of Museum Studies: Museum Theory, John Wiley \& Sons, Ltd., 211 - 231. ISBN 9781405198509

BIRCH, Jo (2018). Museum spaces and experiences for children - ambiguity and uncertainty in defining the space, the child and the experience. In: Children's Geographies, 16(5): 516-528. ISSN 1473-3277

COFFEE, Kevin (2008). Cultural Inclusion, Exclusion and the Formative Roles of Museums. In: Museum Management and Curatorship, 23(3): 261-279. ISSN 1872-9185

CSIKSZENTMIHALYI, Mihaly (2014). Flow and the Foundations of Positive Psychology. Dordrecht: Springer. ISBN 9789401790888

DEBENEDETTI, Stéphane - CARO, Florence - KREBS, Anne (2000). "I"d Rather Play Than Look at Statues": The Experiences of Children with Art Works and Interactive Devices at an Art Exhibition'. In: International Journal of Arts Management, 11(3): 46-58 ISSN 1480-8986

DICKS, Bella - BAMBO, Soyinka - COFFEY, Amanda (2006). Multimodal Ethnography. In: Qualitative Research, 6(1): 77-96. ISSN 1741-3109

FALK, John (2009). Identity and the Museum Visitor Experience. London: New York: Routledge ISBN 9781598741636

FALK, John H. (1991). Analysis of the behavior of family visitors in natural history museums. In: Curator, 34(1): 44-50. ISSN 0011-3069

FALK, John H. - DIERKING, Lynn D. (2000). Learning from Museums. Visitor Experiences and the Making of Meaning. Walnut Creek, CA: AltaMira Press. ISBN 9780742502956

GIUSTI, Ellen (2008). Improving Visitor Access. In: TALLON, Loïc - WALKER, Kevin (eds.). Digital Technologies and the Museum Experience - Handheld Guides and Other Media. Lanham: AltaMira Press, 97-108. ISBN 9780759112377

GRØN, Karen (2011). Empower the Audience! Audience through Deliberate and Strategic Use of Experience and Learning Theories. In: FRITSCH, Juliette (ed.). Museum and Gallery Interpretation and Material Culture. London: New York: Routledge, 204-217. ISBN 9780415885751

HELAL, Dina - MAXSON, Heather - ANCELET, Jeanine. (2013). Lessons Learned: Evaluating the Whitney's Multimedia Guide. In: PROCTOR, Nancy - TELLIS Chris (eds.). Museums and the Web 2013. Silver Spring, MD: Museums and the Web, accessed May 29, 2019. https://mw2013.museumsandtheweb.com/paper/lessons-learned-evaluating-thewhitneys-multimedia-guide/. ISBN 9780985227128 
HOOPER GREENHILL, Elaine. (1992). Museums and the Shaping of Knowledge. London: New York: Routledge. ISBN 0203724062

JENSEN, Nina (1994). Children's Perceptions of Their Museum Experiences: A Contextual Perspective. In: Children's Environments, 11(4): 300-324. ISSN 20510780

JEWITT, Carey. (2012). Digital technologies in museums: New routes to engagement and participation. In: Designs for Learning, 5(1-2): 74-93. ISSN 2001-7480

JOHANSON, Katya - GLOW, Hilary (2012). 'It's not enough for the work of art to be great': Children and Young People as Museum Visitors. In: Participations - Journal of Audience and Reception Studies, 9(1): 26-42. ISSN 1749-8716

JONCHERY, Anne - BIRAUD, Sophie (2014). Musées en famille, familles au Musée. De l'expérience de visite des familles à des politiques muséales spécifiques. In: Informations Sociales, 1(181): 86-95. ISSN 2101-0374

LATIMER, Sue (2011). Art for Whose Sake? In: FRITSCH, Juliette (ed.). Museum Gallery Interpretation and Material Culture. London: New York: Routledge, 67-79. ISBN 9780415885751

LUTZ, Catherine (2017). What matters. In: Cultural Anthropology, 32(2): 181-191.

ISSN 0886-7356, online ISSN 1548-1360.

MOORHOUSE, Natasha, TOM DIECK Claudia M. - JUNG, Timothy (2019). An experiential view to children learning in museums with Augmented Reality. In: Museum Management and Curatorship, 34(4): 402-418. ISSN 1872-9185

NEWMAN, Andrew - MCLEAN, Fiona. (2003). Architectures of Inclusion: Museums, Galleries and Social Inclusion. In: Sandell, Richard (ed.). Museums, Society, Inequality. Taylor \& Francis e-Library, 56-68. ISBN 0203167384

O’NEILL, Mark. (2003). "The Good Enough Visitor.” In Sandell, Richard (ed.). Museums, Society, Inequality. London: New York: Routledge, 24-40. ISBN 0203167384

PARIS, Scott. (1997). Situated Motivation and Informal Learning. In: Journal of Museum Education, 22(2-3): 22-26. ISSN 1059-8650

PARRY, Ross. (2001). Including Technology. Can New Media Really Help Museums to Meet the Inclusion Agenda. In: DODD, Jocelyn - SANDELL, Richard (eds.). Including Museums. Perspectives on Museums, Galleries and Social Inclusion. Leicester: Research Centre for Museums and Galleries, University of Leicester, 104-108. ISBN 189848919X

PINK, Sarah. (2011). Multimodality, multisensoriality and ethnographic knowing: Social semiotics and the phenomenology of perception. In: Qualitative Research, 11(3): 261-276. ISSN 1741-3109

PISCITELLI, Barbara - ANDERSON, David. (2001). Young children's perspectives of museum settings and experiences. In: Museum Management and Curatorship, 19(3): 269-282. ISSN 1872-9185

RENNICK-EGGLESTONE, Stefan - BRUNDELL, Patrick - KOLEVA, Boriana ROUSSOU, Maria - CHAFFARDON, Christophe - BENFORD, Steve. (2016). Families and mobile devices in museums: designing for integrated experiences. In: Journal on Computing and Cultural Heritage, 9(2): 11/1-11/13. ISSN 1556-4711

ROUSSOU, Maria - KATIFORI, Akrivi. (2018). Flow, Staging, Wayfinding, Personalization: Evaluating User Experience with Mobile Museum Narratives. In: Multimodal Technologies and Interaction, 2: 1-32. ISSN 2414-4088 
RUBINO, I. - BARBERIS, C. - XHEMBULLA, J. - MALNATI, G. (2015). Integrating a location-based mobile game in the museum visit: Evaluating Visitors' Behaviour and Learning. In: Journal on Computing and Cultural Heritage, 8(3): 1-18. ISSN 1556-4711

SAMIS, Peter (2019) Revisiting the utopian promise of interpretive media. An autoethnographic analysis drawn from art museums, 1991 - 2017. In: DROTNER, Kirsten - DZIEKAN, Vince - PARRY, Ross - SCHRØDER, Kim Christian (eds.). The Routledge Handbook of Museum, Media and Communication. London: New York: Routledge, 47-66. ISBN 9780367580438

SAMIS, Peter (2007) Gaining Traction in the Vaseline: Visitor Response to a Multi-Track Interpretation Design for Matthew Barney: DRAWING RESTRAINT. In TRANT J. BEARMAN D. (eds.). Museums and the Web 2007: Proceedings. Toronto: Archives \& Museum Informatics, published March 1, 2007 accessed October 1, 2020. http://www.archimuse. $\mathrm{com} / \mathrm{mw} 2007 /$ papers/samis/samis.html. ISBN 1885626347

SANDELL, Richard (1998). Museums as Agents of Social Inclusion. In: Museum Management and Curatorship, 17(4): 401-418. ISSN 1872-9185

TALLON, Loïc. (2008). Introduction: Mobile, Digital, and Personal. In: TALLON, Loïc WALKER, Kevin (eds.). Digital Technologies and the Museum Experience - Handheld Guides and Other Media. Lanham: AltaMira Press, xvii-xviii. ISBN 9780759112377

TALLON, Loïc - WALKER, Kevin. (2008). Digital Technologies and the Museum Experience: Handheld Guides and Other Media. Lanham, MD: AltaMira Press. ISBN 9780759112377

VAN LEEUWEN, Theo. (2005). Introducing Social Semiotics. London: Routledge. ISBN 0203673425

WEIER, Katrina. (2004). Empowering Young Children in Art Museums: Letting Them Take the Lead. In: Contemporary Issues in Early Childhood, 5(1): 106-116. ISSN 1463-9491 